\title{
Tracking ancient beach-lines inland: 2600-year-old dentate-stamped ceramics at Hopo, Vailala River region, Papua New Guinea
}

Robert Skelly ${ }^{1}$, Bruno David ${ }^{1}$, Fiona Petchey ${ }^{2} \&$ Matthew Leavesley ${ }^{3}$

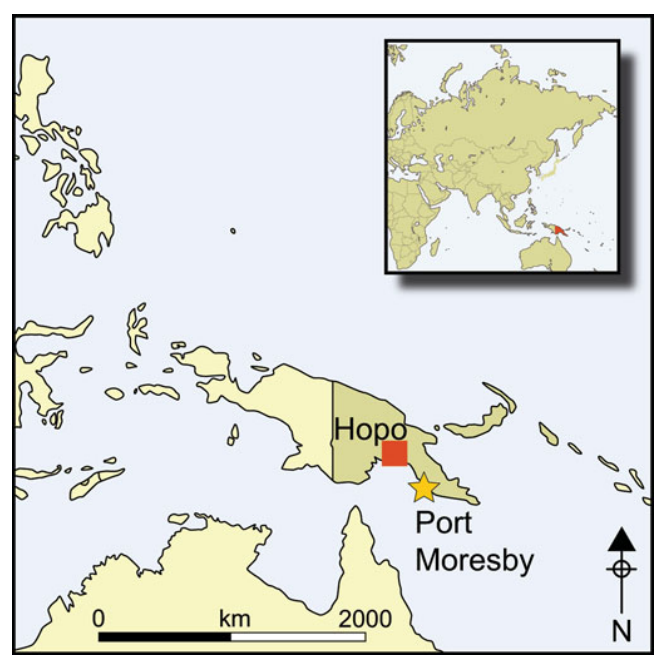

The Lapita expansion took Austronesian seafaring peoples with distinctive pottery eastward from the Bismarck Archipelago to western Polynesia during the late second millennium $B C$, marking the first stage in the settlement of Oceania. Here it is shown that a parallel process also carried Lapita pottery and people many hundreds of kilometres westward along the southern shore of Papua New Guinea. The key site is Hopo, now $4.5 \mathrm{~km}$ inland owing to the progradation of coastal sand dunes, but originally on the sea edge. Pottery and radiocarbon dates indicate Lapita settlement in this location c. 600 BC, and suggest that the long-distance maritime networks linking the entire southern coast of Papua New Guinea in historical times may trace their origin to this period.

Keywords: Papua New Guinea, Vailala River, Hopo, Lapita, seafaring, maritime colonisation, coastal change

\section{Introduction}

Recent archaeological discoveries in the Philippines and the Mariana Islands in Micronesia, north of the island of New Guinea, have shed critical new light and heralded radical new thinking on early Lapita and 'the pottery trail from Southeast Asia to Remote Oceania' (Carson et al. 2013). Summerhayes et al. (2010) and Harlow et al. (2012) have demonstrated

1 Monash Indigenous Centre, Monash University, Clayton, VIC 3800, Australia (Email: robert.skelly@monash.edu; bruno.david@monash.edu)

2 Radiocarbon Dating Laboratory, University of Waikato, Hamilton 3240, New Zealand (Email: fpetchey@waikato.ac.nz)

3 School of Arts and Social Sciences, James Cook University, Cairns, QLD 4870, Australia (Email: matthew.leavesley@jcu.edu.au) 
a degree of interaction linking an early Lapita site on Emirau (in the Bismarck Archipelago) with the Lake Sentani region on the northern coast of New Guinea. Similarly, recent discoveries at Caution Bay have revealed a previously unknown western arm for the spread of mid to late Lapita along the southern coast of New Guinea (David et al. 2011; McNiven et al. 2011; see also Irwin 2012; Specht 2012; Spriggs 2012). These findings, relating to the early and late phases of Lapita, on each side of New Guinea respectively, spatially and temporally bookend this large continental island that has long remained enigmatic on questions of Lapita origins and expansions. These new Lapita discoveries of the past seven years breach what were then the known spatial boundaries of Lapita influence and expand or even bring into question what we thought we knew of the origins and subsequent western movements of Lapita seafaring. Intriguingly, these findings at the margins of the Lapita world open new windows by which to view and explore the nature and dynamics of Lapita, from its origins to its demise or transformation out of what is identifiably Lapita.

The Caution Bay finds confirm the presence of Lapita peoples along the southern coast of mainland Papua New Guinea (PNG) in the later stages of Lapita (here dated to 2900-2600 cal BP) (McNiven et al. 2012). Ceramic finds from Torres Strait to the west (McNiven et al. 2006), consisting of five body sherds lacking decoration, cannot in themselves be conclusively attributed to Lapita given an absence of diagnostic features other than red slipping (which is also present in post-Lapita times elsewhere along the southern coast of PNG), but the Torres Strait sherds-made with local tempers-date to c. $2600 \mathrm{cal} \mathrm{BP}$ (McNiven et al. 2006) and are thus contemporaneous with the late Lapita finds from Caution Bay. No other kinds of ceramics of this age other than Lapita are known from this part of the Pacific. The question nevertheless remains as to whether Caution Bay Lapita villages represent an aberrant western settlement of Austronesian-speaking seafaring colonisers who otherwise only ventured eastward from the Bismarck Archipelago, or whether they are part of a more systematic and more widespread colonisation of westward places, including some that were already inhabited by indigenous populations (see Sheppard 2011 for recent discussion relating to the leap-frogging of previously inhabited islands into Remote Oceania). Here we report the discovery of dentate-stamped pottery sherds, akin to those elsewhere attributed to Lapita pottery, at the Hopo site east of the Vailala River in the Gulf of Papua (PNG National Museum and Art Gallery site code OJS), 230km north-west of Caution Bay as the crow flies (260km following the coastline) and just short of midway to Torres Strait (Figure 1). These findings confirm that the Lapita settlement of Caution Bay was not just an aberrant or opportunistic accident of colonisation by presumably Austronesian seafarers, but rather, we argue, part of a process of systematic expansion and colonisation westward during terminal Lapita times.

\section{Ancient coastlines}

In 2007, pottery sherds dating to 450-500 cal BP were found on buried beach sands at Keveoki swamp, c. $6 \mathrm{~km}$ east of the Vailala River (David et al. 2009). Today Keveoki lies $1.5 \mathrm{~km}$ inland, signalling a shoreline that has prograded at an average rate of $3 \mathrm{~m}$ per year for the past 500 years at least (David et al. 2009: 13). Given the paucity of known older archaeological sites along this coastline (for a review see McNiven et al. 2006), extrapolation

(C) Antiquity Publications Ltd. 


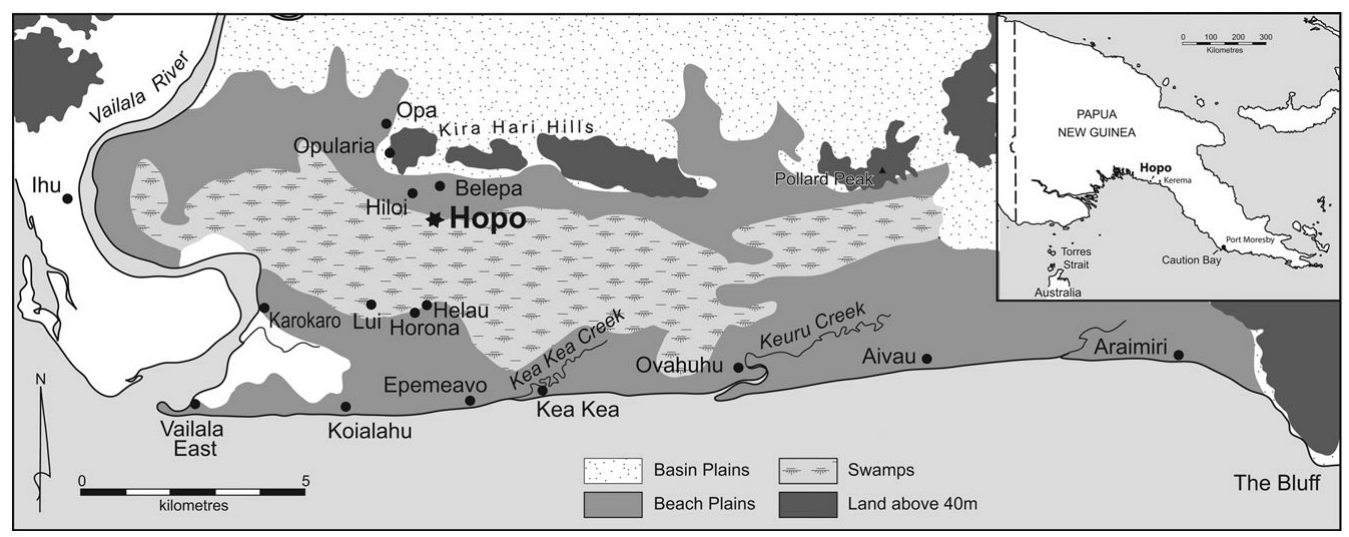

Figure 1. Map of the Kouri lowlands showing the position of Hopo (OJS) and other places mentioned in the text (after Ruxton et al. 1969: map 2).

of progradation rates of $3 \mathrm{~m}$ per year further back in time (a realistic scenario given local surface geomorphology, see Ruxton 1969) signals that sites once fronting the beach that were occupied before 2000 years ago would now lie many kilometres inland.

Indeed, researchers have for some time been aware that in the Gulf of Papua older archaeological sites would now be found inland. In 1976 Jim Rhoads followed Orokolo oral histories—and by implication ancient coastlines-inland, looking for archaeological sites west of the Vailala River (Rhoads 1982: 144, 1994: 66-67; Williams 1969). In 1979, some $55 \mathrm{~km}$ east of the Vailala River, David Frankel and Nigel Oram recorded local oral histories and identified an undated 'chronological series' of archaeological sites in the Kerema lowlands (Frankel \& Vanderwal 1985; Frankel et al. 1994), arguing for the sequential age of coastal deposits and archaeological sites the further one progressed inland.

In 2007 and again in August-October 2010, we undertook archaeological surveys tracking local histories and ancient beach-lines progressively inland from the current coastal villages of Epemeavo and Kea Kea, identifying and excavating 10 new archaeological sites $c .6 \mathrm{~km}$ east of the Vailala River (Skelly et al. 2010; Skelly 2014). These sites were found to represent a well-dated chronological series revealing increasing antiquity with increasing distance from the coast. Here we present the earliest evidence of ceramics - from one of the most inland sites - yet obtained from anywhere on the island of New Guinea other than Caution Bay.

\section{Hopo (OJS)}

Hopo is a Miaro clan (Keuru language group, popularly known by the Motuan word 'Elema') ancestral village site known from local oral traditions. The site is positioned on 1 ha of deflated sand dunes $<1 \mathrm{~km}$ south of the Kira Hari Hills and $4.5 \mathrm{~km}$ inland of the present-day coastline (Figure 1). The archaeological site visible from surface evidence at Hopo was defined by a surface scatter of shell and pottery sherds spread over an area $6 \mathrm{~m}$ long $\times 4 \mathrm{~m}$ wide (maximum 10 artefacts per $\mathrm{m}^{2}$ ) toward the south-eastern edge of the ancestral village site of oral tradition. The upper level occupation dates to the past 200-225 years by: (a) genealogical reckoning from Miaro clan oral traditions which trace site use to (C) Antiquity Publications Ltd. 


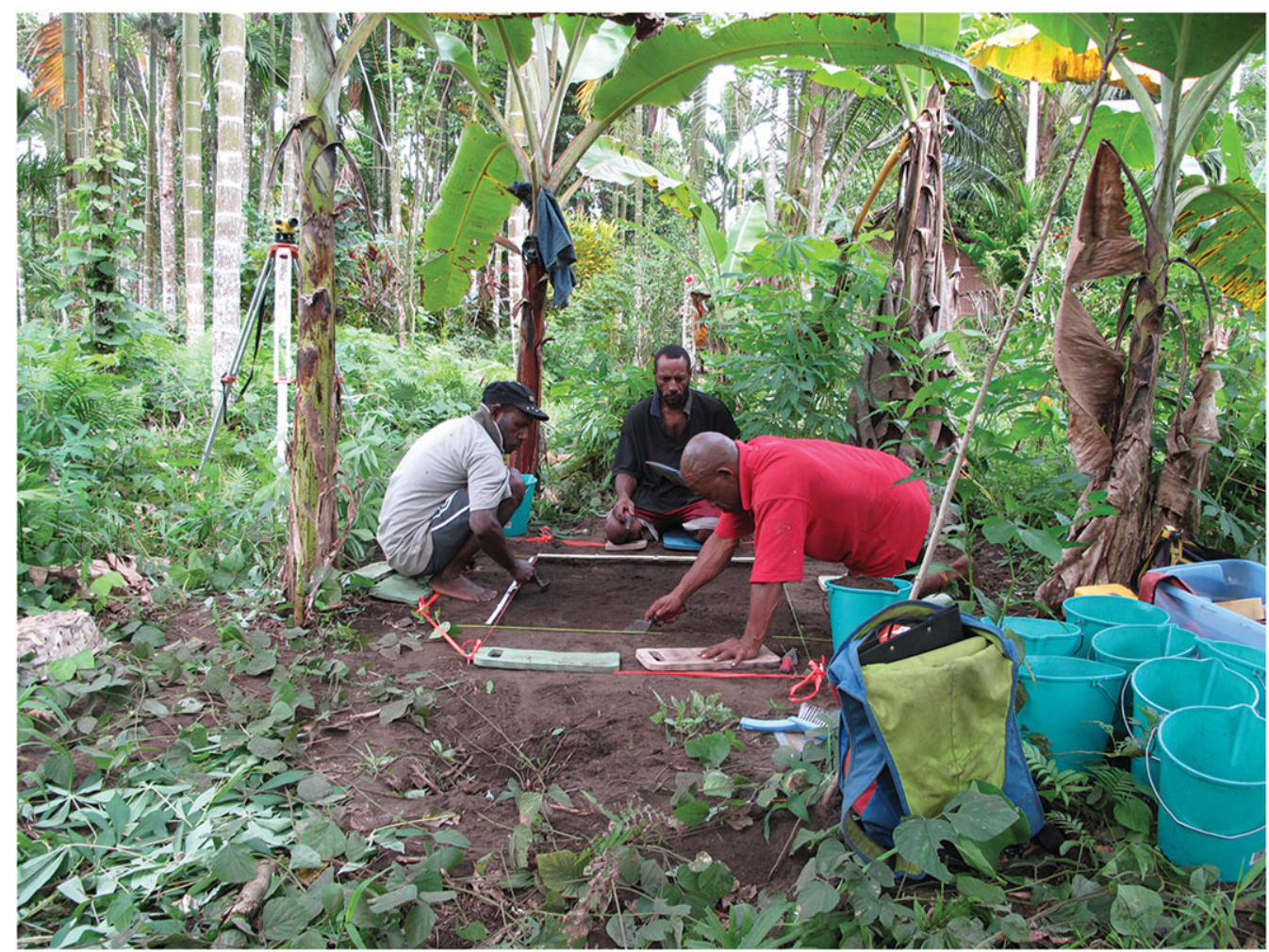

Figure 2. Excavation in progress, OJS Square A (left to right: Alois Kuaso, Francis Kouri and Basil Mali).

six to seven generations before the present adult generation; (b) radiocarbon results; and (c) the fact that this most recent cultural horizon is stratigraphically discontinuous with the deeper and earlier archaeological horizon presented in this paper. Three $1 \mathrm{~m} \times 1 \mathrm{~m}$ squares were excavated in firm sediments on elevated ground (Grid Reference: 03316139125394 [AGD66]), largely surrounded by freshwater swampland $35 \mathrm{~m}$ to the south, $45 \mathrm{~m}$ to the east and $60 \mathrm{~m}$ to the north.

\section{The excavations}

The OJS excavation team included Francis Kouri, Auks Hoahe and Willie Tom from Epemeavo village (Hori Miaro clan), Johnson Opa from Belepa village (Leva Huku clan), Basil Mali and Alois Kuaso representing the PNG National Museum and Art Gallery, and Robert Skelly as excavation director. Excavations commenced on 8 September 2010 and concluded on 17 September 2010 (Figures 2 \& 3).

The three excavation squares share a spatially contiguous stratigraphic sequence. The squares progressively slope down slightly to the east and, accordingly, the depths of transition between individual stratigraphic units (SUs) differ slightly from square to square (Figures 4 \& 5; Table 1). To maintain systematic and fine-grained chronostratigraphic control, each square was excavated and analysed separately. Excavations proceeded in mean

(C) Antiquity Publications Ltd. 


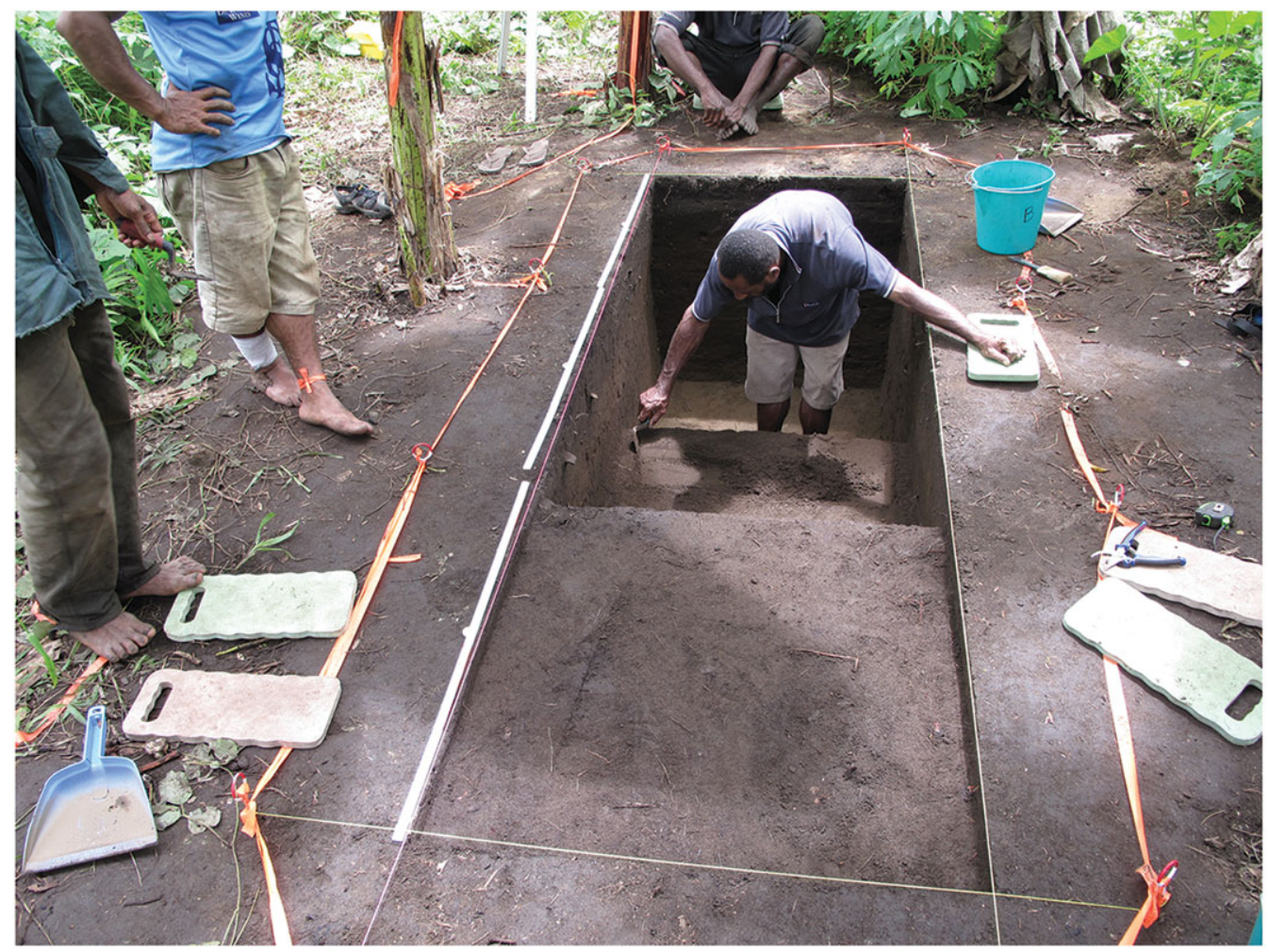

Figure 3. OJS Square A excavations completed, Squares B and C in progress. Excavator: Francis Kouri.

$21 \mathrm{~mm}$ (Square A), 20mm (Square B) and 22mm (Square C) artificial excavation units (XUs) following the stratigraphy where visible during excavation. The OJS stratigraphic sequence contains five major SUs containing four periods of site use, as determined by stratigraphically discrete cultural horizons of significantly different ages (see Table 2 for radiocarbon determinations). Here we report on ceramics from the basal and thus oldest cultural deposit in SU4 (see Skelly 2014 for presentation of the full OJS sequence). SU4 contains moderately consolidated, moderately compacted dark brown sand and a small quantity of pumice. Below SU4, culturally sterile SU5 contains very dark greyish brown, moderately consolidated sand with a minor water-worn coarse sand fraction that increases in overall sediment contribution with increasing depth.

\section{Radiocarbon dating SU4: Squares A, B and C}

Seven AMS radiocarbon determinations on single pieces of wood-charcoal were obtained from the lower levels of SU4. These seven samples were collected over a thickness of $13.4 \mathrm{~cm}$ near the base of SU4 (depth below surface $=62.9-76.3 \mathrm{~cm}$ ) (Figure 4). Unmodelled dates calibrate within the period $2466-2745 \mathrm{cal}$ BP at $68.3 \%$ probability, with median ages hovering around $2600 \mathrm{cal} \mathrm{BP}$ between 2565 and $2713 \mathrm{cal} \mathrm{BP}$ (Table 2).

(C) Antiquity Publications Ltd. 
NORTH

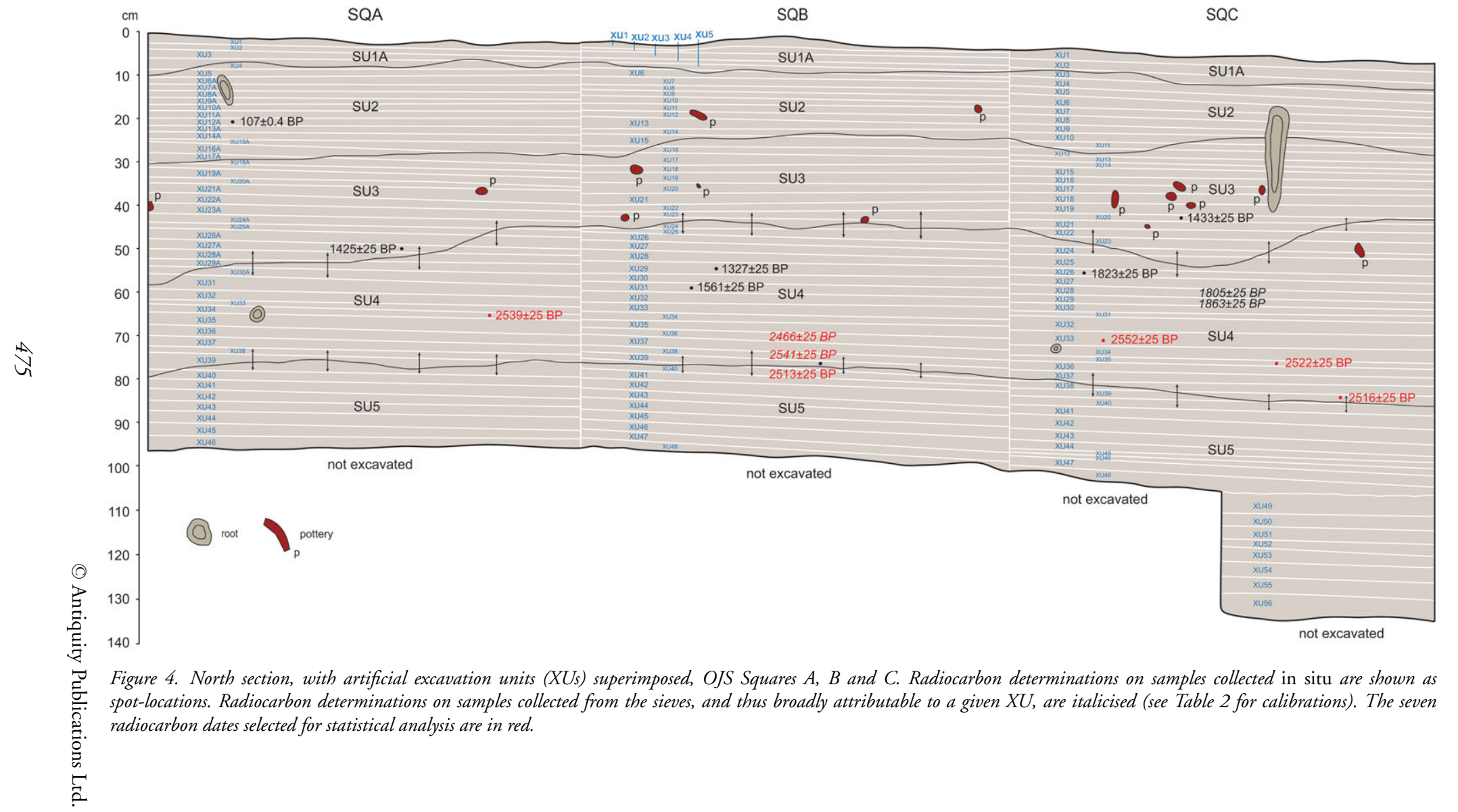




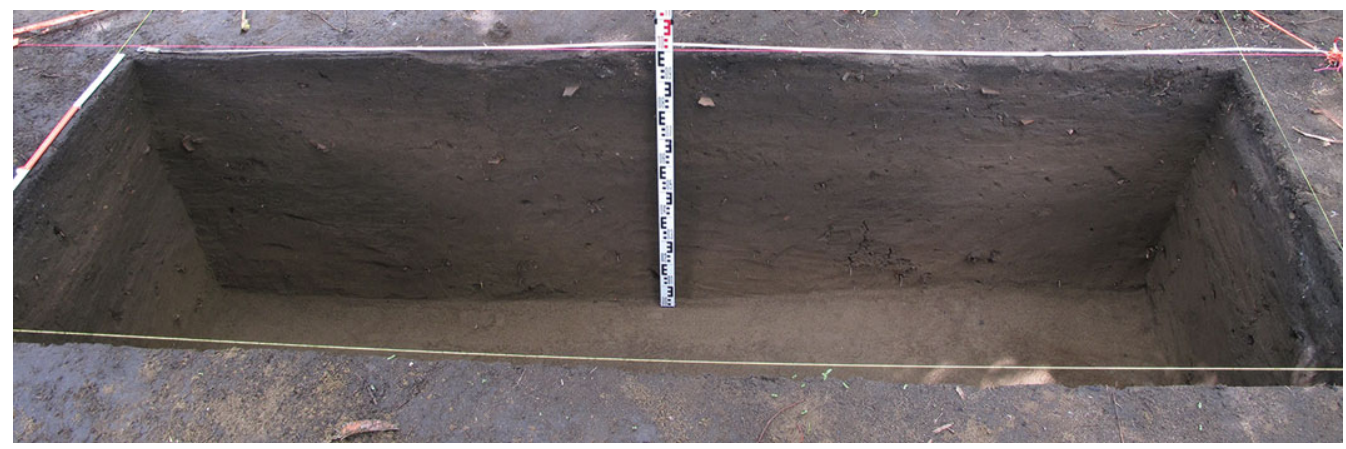

Figure 5. South wall of trench after completion of excavation, OJS Squares A, B and C.

In an attempt to better define the duration of site use covered by the seven deepest and oldest dates we have used OxCal v.4.2 (Bronk Ramsey 2009, 2013) to determine the age of onset and end, and the duration of the SU4 midden deposit. Using a 'phase command' (i.e. assuming that the seven dates are not from an instantaneous event but a random scatter of events in no particular order) with a uniform boundary (Bronk Ramsey 2009), we get a modelled median age of $2668 \pm 69 \mathrm{cal}$ BP for the base of SU4 and $2615 \pm 80 \mathrm{cal}$ BP for the top (Figure 6). This has a span of 0-47 years, indicating a short-lived period of occupation measured at most in a very few decades, possibly very brief. This is consistent with a rapidly prograding shoreline as evident from independent data (see above).

If we apply an outlier correction to the charcoal for inbuilt age $(\operatorname{Exp}(1,-10,0), \mathrm{U}(0,3)$, , $\mathrm{t}$ ”) following Bronk Ramsey (2009), we get a very similar result again, although now slightly younger (by less than 40 years). Because we are limited in this example to samples of wood charcoal of unspecified inbuilt age, and this conclusion relies on a model-averaging approach, we have not explored this further.

\section{The ceramic assemblage}

In total, 3889 low-fired pottery sherds $\geqslant 2 \mathrm{~mm}$ wide (representing the sieve mesh size) were excavated from SU4. Of these, 88 sherds either measure $\geqslant 30 \mathrm{~mm}$ long or are smaller decorated or rim sherds. These 88 sherds constitute the diagnostic assemblage.

\section{Dentate-stamped decoration}

Five decorated sherds from SU4 are dentate-stamped (decoration created with combs or comb-like implements); all are from Square A (XU28-XU37). These five sherds came from at least two vessels, as evident from differences in fabrics and sherd profiles. The largest of the comb-impressed sherds has parallel lines of dentate-stamped impressions emanating from either side of two horizontal dentate-stamped lines (Figures 7a \& 8a). Four of the indented lines consist of discrete rectilinear impressions made by relatively coarse-tined tools (typical of late Lapita across Island Melanesia and Caution Bay) and are clearly combimpressed. The other three lines also appear to have been comb-impressed, but here the dentate impressions have weathered and cracked so that the individual dentitions have (C) Antiquity Publications Ltd. 



Figure 6. OxCal plots showing: A) end probability distribution for deposition of SU4; B-H) probability distributions for the seven radiocarbon determinations; I) modelled deposition span of SU4; J) start probability distribution for deposition of SU4.

become connected during or post firing (and probably post-depositionally). Another sherd has two parallel comb-impressed lines and more ambiguous evidence of a third parallel line (Figures $7 \mathrm{~d} \& 8 \mathrm{~d}$ ). Two additional lines on that same sherd are angled relative to the parallel lines, suggesting that the remnant lines are probably part of an originally larger geometric pattern. The other three sherds came from one or more vessels with a thinner wall (Figures $7 b, c \&$ e and $8 b, c \&$ e). All three sherds have sets of comb dentate-stamped lines hinting at geometric patterning.

(C) Antiquity Publications Ltd. 
Table 1. Sediment descriptions, OJS Squares A, B and C.

\begin{tabular}{|c|c|c|c|c|c|c|c|c|}
\hline \multirow[b]{2}{*}{ SU } & \multirow[b]{2}{*}{ Description } & \multirow[b]{2}{*}{ Dry Munsell } & \multicolumn{3}{|c|}{$\mathrm{pH}$} & \multicolumn{3}{|c|}{$\begin{array}{l}\text { Maximum depth } \\
\text { at base of } S U(\mathrm{~cm})\end{array}$} \\
\hline & & & A & B & $\mathrm{C}$ & A & B & $\mathrm{C}$ \\
\hline $1 \mathrm{~A}$ & $\begin{array}{l}\text { Black, charcoal-stained } \\
\text { organic topsoil, loosely } \\
\text { compacted, consolidated } \\
\text { by numerous rootlets, } \\
\text { homogeneous across the } \\
\text { square }\end{array}$ & 10YR $2 / 1$ & 6.6 & 6.9 & 7.1 & 14 & 10 & 16 \\
\hline 2 & $\begin{array}{l}\text { Very dark brown, } \\
\text { well-consolidated } \\
\text { organic-rich sediment } \\
\text { with minor sand fraction }\end{array}$ & 10 YR $2 / 2$ & 6.5 & 7.0 & 7.0 & 29 & 27 & 24 \\
\hline 3 & $\begin{array}{l}\text { Very dark greyish brown, } \\
\text { well-consolidated sandy } \\
\text { silt; the interface with } \\
\text { SU4 is diffuse }\end{array}$ & 10YR $3 / 2$ & 6.4 & 6.2 & 6.8 & 58 & 45 & 48 \\
\hline 4 & $\begin{array}{l}\text { Dark brown, moderately } \\
\text { consolidated and } \\
\text { moderately compacted } \\
\text { sandy sediments, } \\
\text { homogeneous across } \\
\text { each square. Contains } \\
\text { small quantities of } \\
\text { pumice. The interface } \\
\text { with SU5 is diffuse }\end{array}$ & $10 Y R 3 / 3$ & 6.3 & 6.0 & 6.2 & 81 & 77 & 90 \\
\hline 5 & $\begin{array}{l}\text { Culturally sterile very dark } \\
\text { greyish brown, } \\
\text { moderately consolidated } \\
\text { soft sand. Contains } \\
\text { pumice and a minor } \\
\text { water-worn coarse sand } \\
\text { fraction that increases in } \\
\text { overall sediment } \\
\text { contribution with } \\
\text { increasing depth. Base of } \\
\text { SU was not reached }\end{array}$ & $2.5 \mathrm{YR} 3 / 2$ & 5.9 & 5.8 & 6.0 & 96 & 100 & 133 \\
\hline
\end{tabular}

One comb-impressed sherd has both body and lip decoration (Figures 7e \& 8e). This sherd, apparently from a small bowl, has a comb-impressed horizontal line intersected by diagonal lines on the rim. The lip decoration consists of two longitudinal, parallel dentatestamped lines along the narrow, flat lip.

The decorative conventions found on the five comb-impressed sherds at OJS are entirely unknown from post-Lapita times anywhere along the southern coast of PNG (e.g. Vanderwal 1978; Summerhayes \& Allen 2007; Allen 2010). They are only known from pre-2600 cal BP Lapita deposits at Caution Bay (David et al. 2011; McNiven et al. 2012) — the only (C) Antiquity Publications Ltd. 
Table 2. Radiocarbon determinations for SU4, OJS Squares A, B and C. Samples marked * were retrieved from the sieves (all other samples were collected in situ). All ${ }^{14} \mathrm{C}$ ages are AMS on wood charcoal except Wk-31230, Wk-32237 and Wk-32238 which are on sedge. Calibrations undertaken using OxCal v.4.2 (IntCal09 curve selection) (Bronk Ramsey 2009; Reimer et al. 2009).

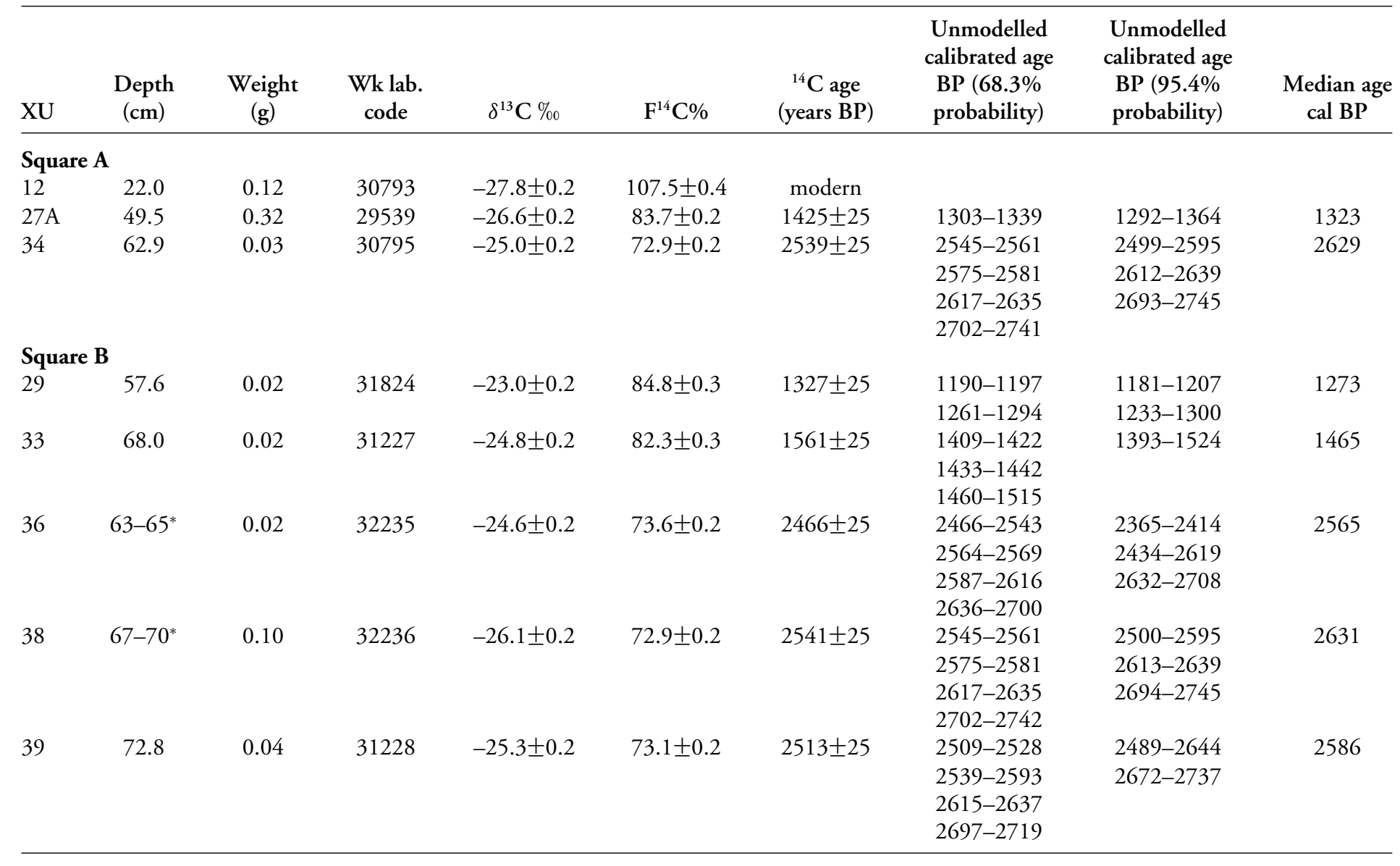









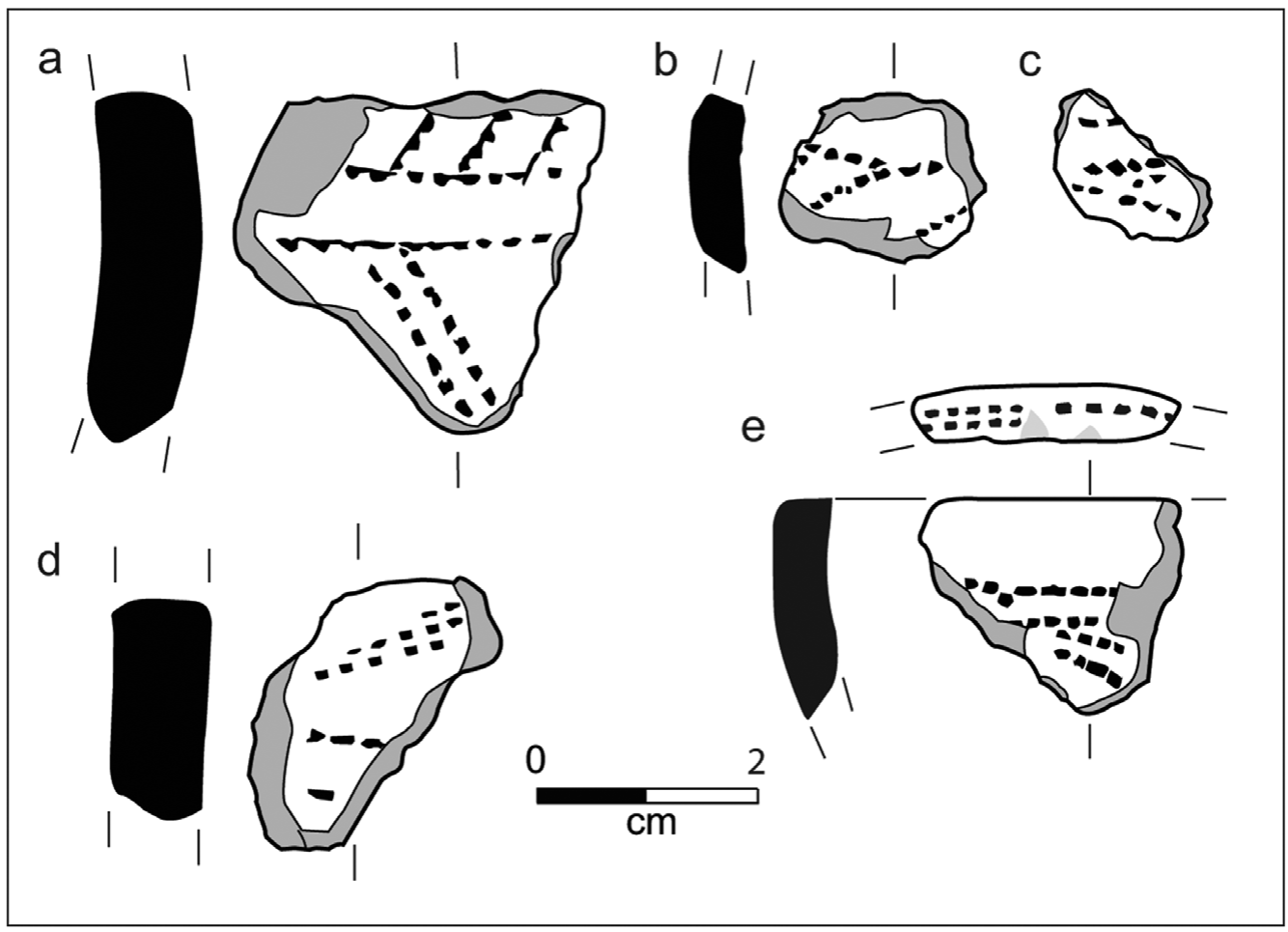

Figure 7. Sherds with comb-impressed decoration, OJS Square A: a) XU28; b) XU37; c) XU37; d) XU29; e) XU37. Drawings by Cathy Carigiet.

stratified Lapita sites yet found on the island of New Guinea-as well as from Lapita sites in Island Melanesia. Examples of similar dentate-stamped Lapita sherds with flat lips from the Solomon Islands are illustrated in Figure 9a-c.

\section{Fingernaillother-tool-impressed decoration}

Two conjoining body sherds from the base of SU4 have fingernail or other tool impressions along a thickened vessel wall, probably a thickened collar (Figures 10a \& 11a). A similarly decorated sherd with fingernail or other tool impressions along a probable thickened collar and along a carination lay horizontally at the base of SU4 immediately above culturally sterile SU5 (at a stratigraphic transition representing an ancient surface); it was removed from the west wall of Square A (see Figures 10b, $11 \mathrm{~b} \& 12$ ). Such fingernail/other tool impressions along thickened collars and carinations are consistent with decorative conventions and positioning along pronounced vessel contours on contemporaneous and near-contemporaneous late Lapita pottery elsewhere in the Pacific, including Caution Bay at $2600 \mathrm{cal} \mathrm{BP}$ (where finger and/or other tool, rather than fingernail, impressions along thickened collars and carinations occur) (e.g. Wahome 1997: 118-19; White \& Harris 1997: fig. 3; Anson 1999; Bedford 1999: 128). 




Figure 8. Sherds with comb-impressed decoration, OJS Square A; a) XU28; b) XU37; c) XU37; d) XU29; e) XU37. Photographs by Steve Morton.

\section{Discussion: hypothesising late Lapita southern coast expansions}

The tracking of ancient beach-lines progressively inland along the southern coast of PNG has led to the recovery of buried dentate-stamped ceramics dating to shortly before $2600 \mathrm{cal}$ BP some $4.5 \mathrm{~km}$ inland from the present coastline. At that time, site OJS was a near-beach or beach-fronting location. These results indicate a mean local coastal progradation rate of $1.6-1.8 \mathrm{~m}$ per year for the past $c .2600$ years.

Five dentate-stamped and three fingernail/other-tool-impressed sherds from this period share decorative conventions only known along the southern coast of PNG from contemporaneous late Lapita sites. This was a time when Lapita pottery was current in the villages of Caution Bay near present-day Port Moresby $230 \mathrm{~km}$ to the east of Hopo (David et al. 2011; McNiven et al. 2011). Thus Lapita influence appears to have extended along the Papuan coastline for at least $645 \mathrm{~km}$ as the crow flies, or $740 \mathrm{~km}$ following the coastline north-west from the eastern tip of New Guinea.

(C) Antiquity Publications Ltd. 

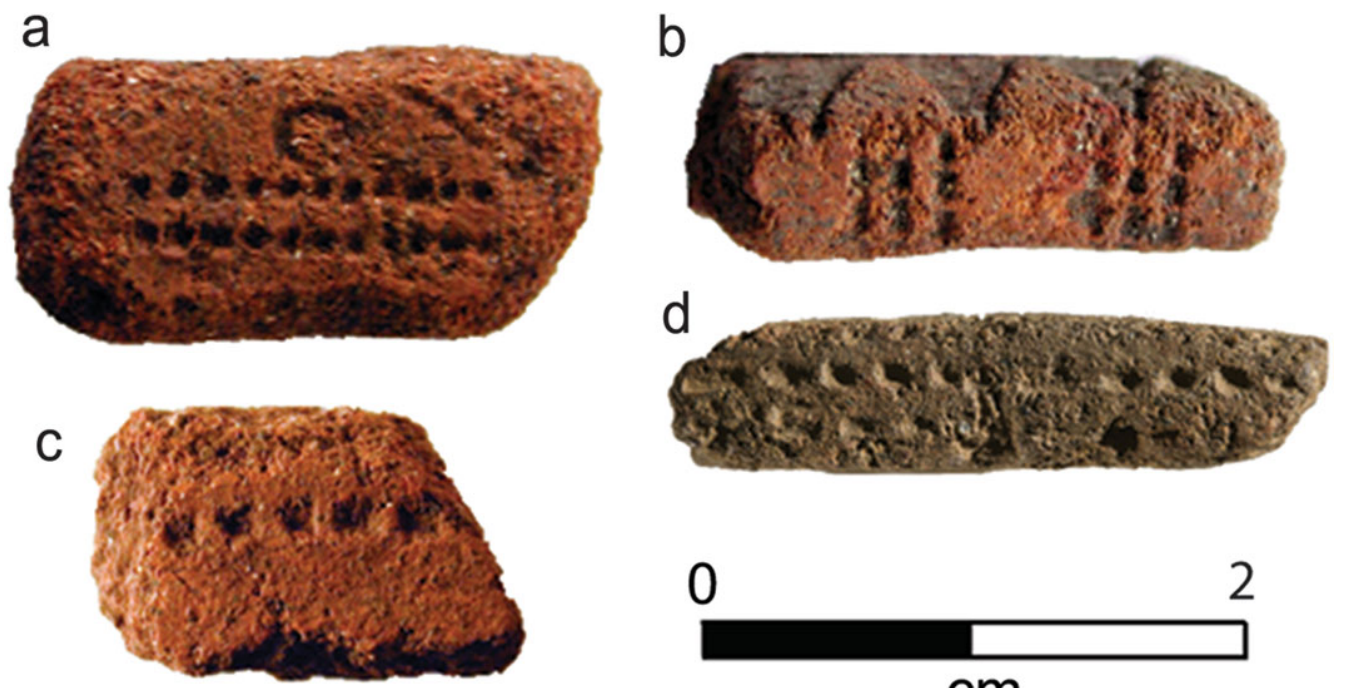

Figure 9. Flat-lipped sherds with dentate-stamped decoration. Sherds $a, b$ and c are from Lapita sites in the Solomon Islands; sherd d is from OJS Square A (archaeological provenance: a) RF6 16/53; b) RF6 29/3; c) SERF2 284/45; d) OJS Square A XU37). Photographs of sherds $a, b$ and c courtesy of the Anthropology Photographic Archive, Department of Anthropology, University of Auckland (http://magic.lbr.auckland.ac.nzlanthpd); photograph of sherd d by Steve Morton.
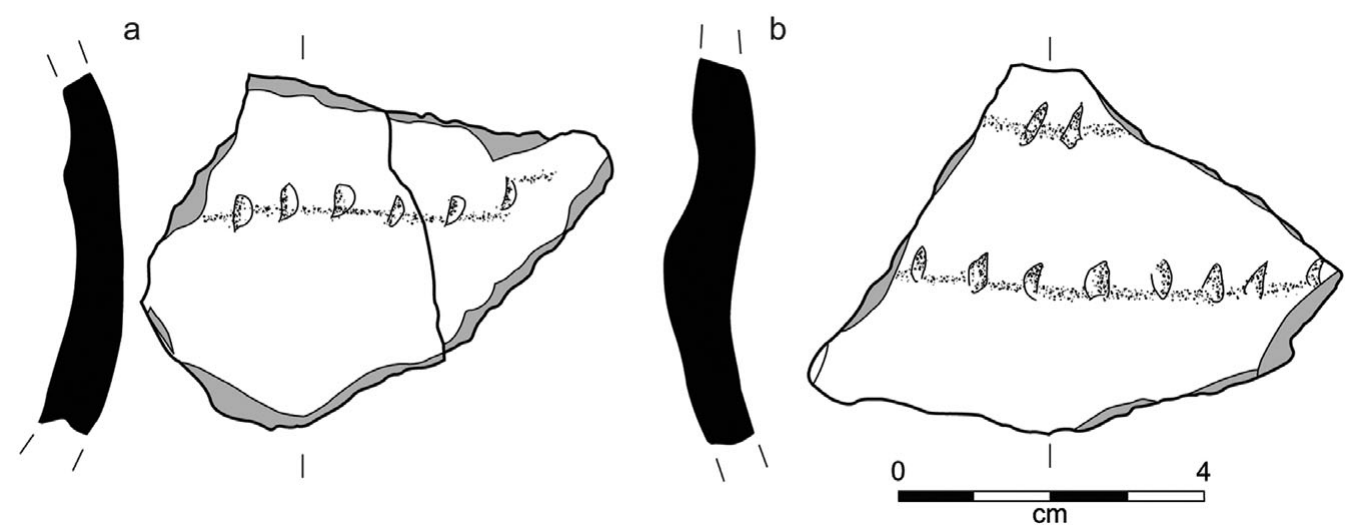

Figure 10. Fingernaillother-tool-impressed sherds: a) Square CXU35; b) sherd removed from the west wall of Square A (see Figure 12). Drawings by Cathy Carigiet.

We do not yet know with any certainty which of a number of colonisation scenarios best explains the Hopo ceramic horizon dated to $c .2600 \mathrm{cal} \mathrm{BP}$, as the recovered archaeological materials are insufficient to tell and radiocarbon dates are ambiguous on this question. The Hopo evidence could signal: 1) the presence of a short-lived Lapita village nearby (perhaps an offshore stilt village); 2) a fleeting and archaeologically instantaneous visit by passing Austronesian-speaking ceramicists; or 3) down-the-line exchange of pots and/or ideas from Austronesian-speaking Lapita people to ancestral non-Austronesian Keuru speakers who are the predecessors of those who currently occupy the region. Nor do we yet know where these

(C) Antiquity Publications Ltd. 


\section{Tracking ancient beach-lines inland}
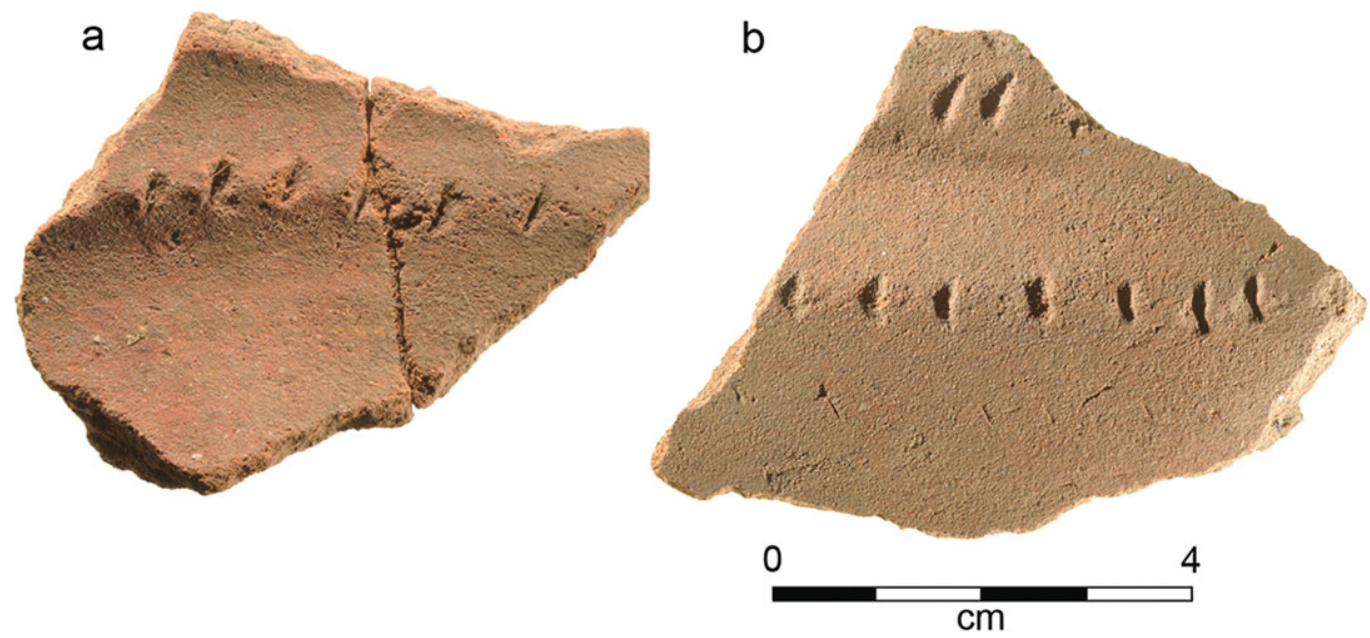

Figure 11. Fingernail/other-tool-impressed sherds: a) Square CXU35; b) sherd removed from the west wall of Square A (see Figure 12). Photographs by Steve Morton.

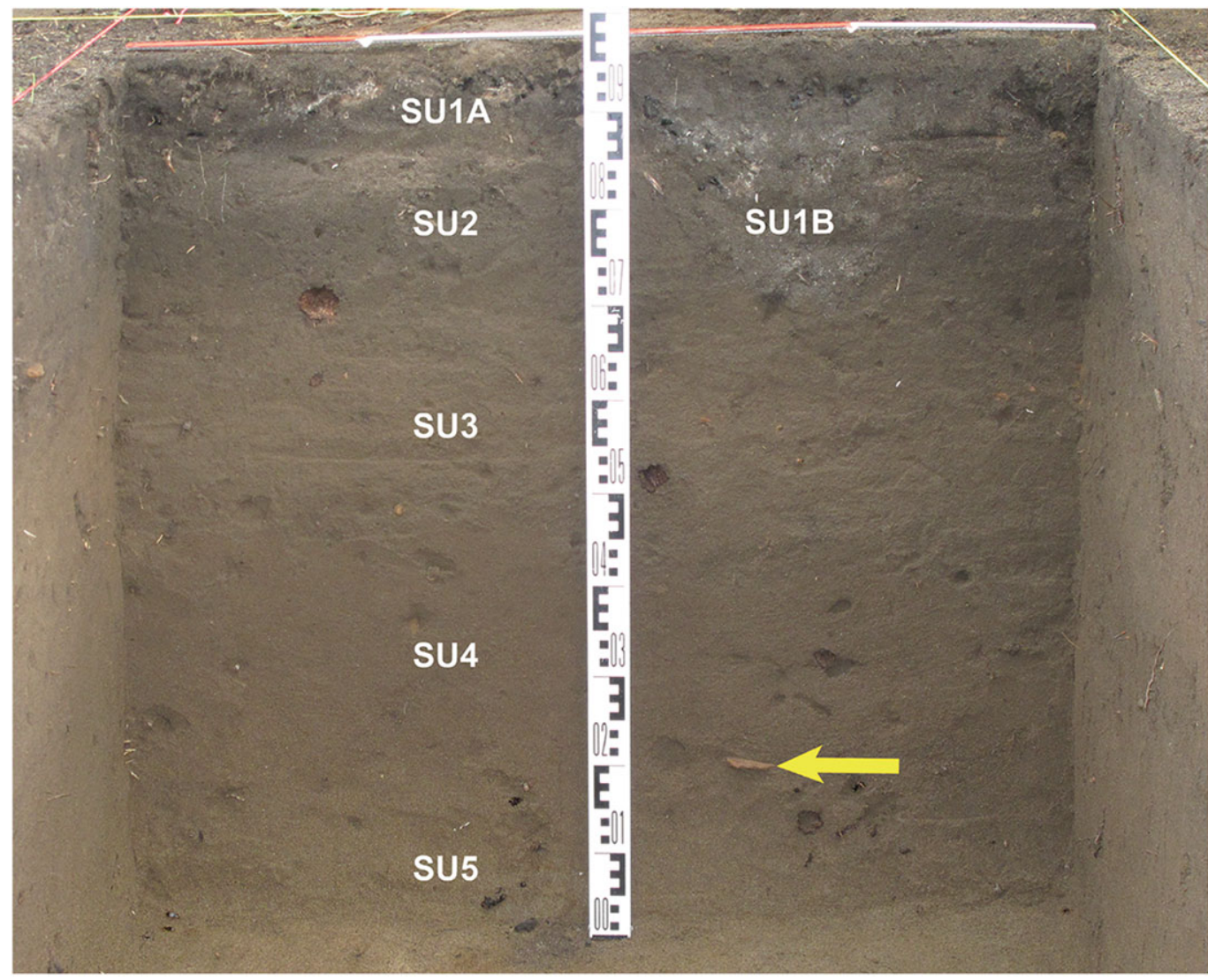

Figure 12. Fingernaillother-tool-impressed sherd lying near the base of SU4 just above culturally sterile SU5 (see Figures $10 b \& 11 b)$.

(C) Antiquity Publications Ltd. 
ceramics were manufactured (temper and clay analyses 'without sources' (Summerhayes \& Allen 2007) are in planning). Equally, we also recognise that in addition to dentatestamped pottery, the Lapita Cultural Complex also includes a range of other items including distinctive axes/adzes made of shell and stone and a range of other portable artefacts (Kirch 1997). Yet the identification of pottery displaying Lapita decorative conventions at Hopo c. 2600 cal BP, coupled with evidence derived from a number of sites around the Gulf of Papua and environs, allow us an opportunity to hypothesise that people living along the Papuan southern coast shared cultural connections with Lapita pottery makers further to the east. Given that the only two other confirmed locations of ceramics of that age along the southern coast are Lapita villages at Caution Bay, and the local manufacture of limited quantities of ceramics of unknown cultural attribution in Torres Strait, we suggest that the Hopo finds represent a local Lapita outpost rather than in-traded ceramics at a non-Lapita settlement. Either way, it would seem unlikely that we have fortuitously located the only Lapita-period Austronesian contact (trade) location or outpost far removed and isolated from communities to the east at Caution Bay, and we expect further investigations to uncover additional evidence of contemporaneous ceramic-using communities in other places along the southern coast of PNG.

Recent discoveries of long-lived Lapita settlements dating from 2900 to $2600 \mathrm{cal} \mathrm{BP}$ at Caution Bay to the east; more ephemeral locally manufactured red-slipped ceramics dating to $2600 \mathrm{cal} \mathrm{BP}$ in Torres Strait to the west; and the onset of the maritime Torres Strait Cultural Complex involving seafaring made possible by the theorised presence of Melanesian outrigger canoes commencing c. 2600 cal BP across Torres Strait (Barham 2000) suggest that Lapita seafarers systematically explored and established settlements along the southern coast of PNG during terminal Lapita times at a time when Lapita was breaking down (as evidenced by the end of dentate-stamped ceramics at Caution Bay c. 2600 cal BP). We hypothesise that this period of expansion witnessed heightened levels of seafaring by Austronesian-speaking terminal Lapita peoples expanding westward as emerging generations opened up their world towards new territorial and social opportunities in the face of increasing population levels. The Proto-Oceanic (ancestral to most Oceanic languages) terms * qa-lapa(s) ('chief, senior person of a descent group'), *qa-diki ('first-born son of a chief') and related terms flag the practice of hereditary chieftainship among Austronesian-speaking Lapita peoples and the privileged position of first-born sons in continuing male lineages, signalling also the need for subsequent sons to establish their own lineages in new places (Pawley 1982; Bellwood 1996: 20-21). The expansions seen along the southern coast of PNG during late Lapita times may be symptomatic of increasing populations and the departure of non-first-born sons from home villages to establish offshoot male lineages in connected but novel locations. In doing so, founder populations created networks of connected but semi-independent outposts. In time, these led to the situation known ethnographically, where long-distance maritime trade linked the entire southern coast of PNG in an inter-connected chain of communication and interaction. We suggest that further exploration of Lapita presence this far west should 
target now-inland coastlines along the northern and southern coasts of New Guinea to the west of the 'Lapita homeland' in the Bismarck Archipelago.

\section{Acknowledgements}

We are grateful to the people of Epemeavo, Kea Kea, Opularia, Hiloi and Belepa villages, whose generous support and friendship made fieldwork possible. We sincerely thank Francis Kouri, Auks Hoahe, Willie Tom and Johnson Opa, without whose dedicated commitment to the task at hand, excavations at Hopo could not have been completed. Special thanks to Hoahe Merere, Tom Haeae and Ben Lahumu for guiding us on site surveys in difficult weather conditions during May and June 2010. We also thank the Hon. Mr Solomon Ope, whose enthusiasm and advice was greatly appreciated. Many thanks also to the PNG National Museum and Art Gallery under whose auspices this research was undertaken, and to Herman Mandui, Alois Kuaso and Basil Mali of the Museum, and the University of Papua New Guinea staff and students, for their ongoing support. Thanks to Monash University for a PhD scholarship to RS, and the Australian Research Council for Discovery grants and QEII and DORA Fellowships DP0877782 and DP130102514 (to BD); and to two referees for comments.

\section{References}

Allen, J. 2010. Revisiting Papuan ceramic sequence changes: another look at old data. The Artefact 33: 4-15.

Anson, D. 1999. Compositional analysis of dentate-stamped Lapita and nail-incised and applied relief pottery from Watom Island, in J.C. Galipaud \& I. Lilley (ed.) The Pacific from 5000-2000 BP: colonisation and transformations: 85-103. Noumea: IRD.

BARHAM, A.J. 2000. Late Holocene maritime societies in the Torres Strait Islands, northern Australia: cultural arrival or cultural emergence?, in S. O'Connor \& P. Veth (ed.) East of Wallace's Line: studies of past and present maritime cultures of the Indo-Pacific region: 223-314. Rotterdam: A.A. Balkema.

BEDFORD, S. 1999. Lapita and post-Lapita ceramic sequences from Erromango, southern Vanuatu, in J.C. Galipaud \& I. Lilley (ed.) The Pacific from 5000-2000 BP: colonisation and transformations: 128-37. Noumea: IRD.

BeLLWOOD, P. 1996. Hierarchy, founder ideology and Austronesian expansion, in J.J. Fox \& C. Sather (ed.) Origins, ancestry and alliance: explorations in Austronesian ethnography: 19-42. Canberra: ANU E-Press.

Bronk RAMSEY, C. 2009. Bayesian analysis of radiocarbon dates. Radiocarbon 51: 337-60.

- 2013. OxCal Program v.4.2. Oxford: Radiocarbon Accelerator Unit, University of Oxford.

Carson, M.T., H.-C. Hung, G. Summerhayes \& P. BELLWOOD. 2013. The pottery trail from Southeast Asia to Remote Oceania. The Journal of Island and Coastal Archaeology 8: 17-36. http://dx.doi.org/10.1080/15564894.2012.726941

(C) Antiquity Publications Ltd.
David, B., N. Araho, B. Barker, A. Kuaso \& I. MoffAT. 2009. Keveoki 1: exploring the hiri ceramics trade at a short-lived village site near the Vailala River, Papua New Guinea. Australian Archaeology 68: 11-23.

DAVID, B., I.J. MCNiven, T. Richards, S.P. Connaughton, M. Leavesley, B. Barker \& C. Rowe. 2011. Lapita sites in the Central Province of mainland Papua New Guinea. World Archaeology 43: 580-97. http://dx.doi.org/10.1080/00438243.2011.624720

FranKel, D. \& R. VANDERWAL. 1985. Prehistoric research in Papua New Guinea. Antiquity 59: 113-15.

Frankel, D., K. Thompson \& R. VAnderWal. 1994. Kerema and Kinomere, in D. Frankel \& J.W. Rhoads (ed.) Archaeology of a coastal exchange system: sites and ceramics of the Papuan Gulf (Research Papers in Archaeology and Natural History 25): 1-49. Canberra: Research School of Pacific and Asian Studies, Australian National University.

Harlow, G.E., G.R. Summerhayes, H.L. Davies \& E. Matisoo-Smith. 2012. A jade gouge from Emirau Island, Papua New Guinea (Early Lapita context, 3300 BP): a unique jadeitite. European Journal of Mineralogy 24: 391-99. http://dx.doi.org/10.1127/0935-1221/2012/00242175

IRWIN, G.R. 2012. Some comments and questions about newly discovered Lapita sites at Caution Bay, near Port Moresby. Australian Archaeology 75: 8-24.

KIRCH, P.V. 1997. The Lapita peoples: ancestors of the Oceanic world. Oxford: Blackwell.

McNiven, I.J., W.R. Dickinson, B. DAVID, M.I. Weisler, F. VON GNielinski, M. CARTER \& U. ZoppI. 2006. Mask Cave: red-slipped pottery and the Australian-Papuan settlement of Zenadh Kes (Torres Strait). Archaeology in Oceania 41: 49-81. 
McNiven, I.J., B. David, T. Richards, K. Aplin, B. Asmussen, J. Mialanes, M. Leavesley, P. FAULKNER \& S. UlM. 2011. New direction in human colonisation of the Pacific: Lapita settlement of south coast New Guinea. Australian Archaeology 72: 1-6.

McNiven, I.J., B. David, T. Richards, C. Rowe, M. Leavesley, J. Mialanes, S.P. Connaughton, B. Barker, K. Aplin, B. Asmussen, P. FaulKner \& S. ULM. 2012. Lapita on the south coast of Papua New Guinea: challenging new horizons in Pacific archaeology. Australian Archaeology 75: 16-22.

PAWLEY, A.K. 1982. Rubbish-man commoner, big-man chief?, in J. Siikala (ed.) Oceanic studies: essays in honour of Aarne A. Koskinen: 33-52. Helsinki: Finnish Anthropological Society.

Reimer, P.J., M.G.L Baillie, E. Bard, A. Bayliss, J.W. Beck, P.G BlackWell, C. Bronk Ramsey, C.E. Buck, G.S. Burr, R.L. EdWards, M. Friedrich, P.M. Grootes, T.P. GuILdERSON, I. Hajdas, T.J. Heaton, A.G. Hogg, K.A. Hughen, K.F. Kaiser, B. Kromer, F.G. MCCORMAC, S.W. MANNING, R.W. Reimer, D.A. Richards, J.R. SOUTHON, S. TAlamo, C.S.M, Turney, J. VAN DER Plicht $\&$ C.E. WeYHENMEYER. 2009. IntCal09 and Marine09 radiocarbon age calibration curves, 0-50,000 years cal BP. Radiocarbon 51: 1111-50.

RhoAds, J.W. 1982. Prehistoric Papuan exchange systems: the hiri and its antecedents, in T.E. Dutton (ed.) The hiri in history: further aspects of long distance Motu trade in central Papua (Pacific Research Monograph 8): 131-51. Canberra: Research School of Pacific Studies, Australian National University.

- 1994. The Popo site, in D. Frankel \& J.W. Rhoads (ed.) Archaeology of a coastal exchange system: sites and ceramics of the Papuan Gulf (Research Papers in Archaeology and Natural History 25): 53-69. Canberra: Research School of Pacific and Asian Studies, Australian National University.

RuXTON, B.P. 1969. Regional description of the Kerema-Vailala area, in B.P. Ruxton, P. Bleeker, B.J. Leach, J.R. McAlpine, K. Paijmans \& R. Pullen, Lands of the Kerema-Vailala Area, Territory of Papua and New Guinea (Land Research Series 23): 9-16. Melbourne: CSIRO.
Ruxton, B.P., P. BleEKer, B.J. Leach, J.R. McAlpine, K. Paijmans \& R. Pullen. 1969. Lands of the Kerema-Vailala Area, Territory of Papua and New Guinea (Land Research Series 23). Melbourne: CSIRO.

SHEPPARD, P.J. 2011. Lapita colonization across the Near/Remote Oceania boundary. Current Anthropology 52: 799-840. http://dx.doi.org/10.1086/662201

SKELLY, R. 2014. From Lapita to the hiri: archaeology of the Kouri lowlands, Gulf of Papua, Papua New Guinea. Unpublished PhD dissertation, Monash University.

Skelly, R., B. David, B. Barker, A. Kuaso \& N. AraHo. 2010. Migration sites of the Miaro clan (Vailala River region, Papua New Guinea): tracking Kouri settlement movements through oral tradition sites on ancient landscapes. The Artefact 33: 16-29.

SpeCHT, J. 2012. Caution Bay and Lapita pottery: cautionary comments. Australian Archaeology 75: 3-7.

Spriggs, M. 2012. Comment. Australian Archaeology 75: 15-16.

Summerhayes, G.R. \& J. Allen. 2007. Lapita writ small? Revisiting the Austronesian colonization of the Papuan south coast, in S. Bedford \& S. Connaughton (ed.) Oceanic explorations: Lapita and western Pacific settlement (Terra Australis 26): 97-122. Canberra: Australian National University.

Summerhayes, G.R., E. Matisoo-Smith, H. Mandui, J. Allen, J. Specht, N. Hogg \& S. McPherson. 2010. Tamuarawai (EQS): an early Lapita site on Emirau, New Ireland, PNG. Journal of Pacific Archaeology 1: 62-75.

VANDERWAL, R.L. 1978. Exchange in prehistoric coastal Papua. Mankind 11: 416-28. http://dx.doi.org/10.1111/j.18359310.1978.tb00670.x

WaHOME, E. 1997. Continuity and change in Lapita and post-Lapita ceramics: a review of evidence from the Admiralty Islands and New Ireland, Papua New Guinea. Archaeology in Oceania 32: 118-23.

White, J.P. \& M. HARRIS. 1997. Early Lapita period obsidian in the Bismarck Archipelago. Archaeology in Oceania 32: 97-107.

Williams, F.E. 1969. Drama of Orokolo: the social and ceremonial life of the Elema. Oxford: Oxford University Press.

Received: 28 May 2013; Accepted: 8 August 2013; Revised: 12 August 2013

(C) Antiquity Publications Ltd. 